\title{
TOLERANSI DA’WAH MOHAMMAD NATSIR
}

\author{
DOI: https://doi.org/10.38214/jurnaldawahstidnatsir.v4i01.98
}

\section{LUKMAN}

lukman@stidnatsir.ac.id

STID Mohammad Natsir - Indonesia

\section{SITI NUR FADLILAH}

fadlilah@stidnatsir.ac.id

STID Mohammad Natsir - Indonesia

\begin{abstract}
ABSTRAK
Da'wah pada hakikatnya harus tegak diatas sendi-sendi toleransi, yaitu menyampaikan hujjah yang benar dan tidak memaksakan suatu keyakinan kepada orang lain. Toleransi dalam arti tasamub dalm Islam mempunyai prinsip-prinsip yang harus ditegakkan dalam aktivitas da'wah. Mohammad Natsir sebagai seorang da'i sangat paham dan menyadari hal tersebut sehingga dalam aktivitas da'wahnya senantiasa didasarkan dan merujuk kepada Al-Qur'an dan As-Sunnah serta pengamalan para sahabat Nabi. Penelitian ini adalah penelitian kepustakaan (library research), di mana peneliti melakukan penelusuran, analisa, dan penelaahan terhadap aktivitas-aktivitas da'wah Mohammad Natsir yang terekam dalam karya-karya beliau dan juga literatur yang terkait dengan penelitian ini. Dari hasil penelitian ini dapat disimpulkan bahwa da'wah Mohammad Natsir dalam berbagai bidang sangat sarat dengan nilai-nilai toleransi, antara lain toleransi da'wah Mohammad Natsir dalam hubungan antar umat beragama, toleransi da'wah Natsir dalam dunia politik. Seorang da'i, baik sebagai politisi, birokrat, dokter, guru maupun masyarakat biasa dalam menjalankan da'wahnya harus senantiasa memancarkan nilai-nilai tasamuh atau toleransi Islam.
\end{abstract}

Kata kunci: toleransi, da'wah, Mohammad Natsir

\section{PENDAHULUAN}

Toleransi adalah problem bangsa yang tak kunjung selesai, sejak zaman kemerdekaan hingga kini setelah Indonesia merdeka 75 tahun, intoleransi ditengah-tengah masyarakat masih saja tinggi. Tuduhan intoleransi pun sering dialamatkan suatu kelompok kepada kelompok lain, satu individu kepada individu lainnya, bahkan sampai pada tindakan intoleransi seperti pelarangan, pembubaran dan pengrusakan serta penganiayaan. Pada sisi lain redefinisi terhadap makna toleransi pun banyak dilakukan baik oleh individu, lembaga masyarakat maupun pemerintah dengan tujuan untuk menciptakan kehidupan yang damai. Dalam konteks inilah kemudian sangat urgen untuk melihat M. Natsir sebagai sorang tokoh bangsa, tokoh Islam, da'i dan sekaligus seorang politisi yang mampu 
mempraktekkan toleransi dalam kehidupannya. Mohammad Natsir adalah tokoh yang dikenal sangat toleran dalam kehidupannya. Ia berhubungan sangat baik dengan tokoh-tokoh beragama non muslim. Misalnya, Natsir berkawan akrab dengan I.J. Kasimo, mantan ketua Partai Katolik di masa Orde Lama.

Selain keteladanan, Natsir juga adalah tokoh Islam yang aktif memperjuangkan terwujudnya kehidupan antar umat beragama yang toleran di Indonesia. Hal ini terlihat dari usaha-usaha yang dilakukannya, baik ketika menjadi pejabat di pemerintahan, maupun ketika ia berada di luar pemerintahan sebagai orang biasa. Natsir banyak menjelaskan tentang konsep toleransi dalam ceramah dan tulisan-tulisannya. Setidaknya ada beberapa pidato, khutbah dan buku yang ditulisnya khusus tentang toleransi dan hubungan antar umat beragama. Baik dalam politik maupun dalam bermasyarakat. Dalam salah satu tulisannya beliau menyebutkan "Tanpa toleransi tidak ada kerukunan".

\section{Profil Singkat M. Natsir}

M. Natsir terlahir di Jembatan Berukir Alahan Panjang, Kabupaten Solok Sumatera Barat pada hari Jum'at tanggal 17 Jumadil Akhir 1326H, bertepatan dengan tanggal 17 Juli 1908 dari seorang wanita yang bernama Khadijah. Ayahnya bernama Mohammad Idris Sutan Saripado, seorang pegawai rendah yang pernah menjadi juru tulis pada kantor Kontroler ${ }^{1}$ di Maninjau. Di tempat kelahirannya itu, ia melewati masa-masa sosialisasi keagamaan dan intelektualnya yang pertama. $^{2}$

Mohammad Natsir banyak bergaul dengan pemikir-pemikir Islam, seperti Agus Salim, sepanjang pertengahan 1930-an, Mohammad Natsir dan Agus Salim selalu bertukar pikiran perihal kaitan Islam dengan negara demi masa depan pemerintahan Indonesia yang dipimpin Soekarno.

Satu hal yang menarik dalam diri M. Natsir dibalik jabatan-jabatanya dan dipuji semua orang adalah teladan kesederhanaan, dan akhlaqnya. M. Natsir adalah orang yang santun, bersih, konsisten, toleran, tapi teguh pendirian. M. Natsir hidup di zaman Indonesia seperti dalam sebuah lingkaran setan yang tak terputus: regenerasi kepemimpinan terjadi, tapi birokrasi dan politik bersih, kesejahteraan sosial yang lebih baik, terlalu jauh dari jangkauan. Natsir seolah-

1 Berasal dari bahasa Belanda: Caontroleur, adalah sebuah jabatan pemerintahan yang pernah ada di Indonesia pada zaman Hindia Belanda. kontrolir dianggap sebagai koordinator pengawasan dari pemerintahan Belanda hingga ke tingkat paling rendah, di struktur pemerintahan Hindia Belanda.

2 Thohir Luth, M. Natsir Da'wah Dan Pemikiranya (Jakarta: Gema Insani, 1999). h.22 
olah wakil sosok yang berada di luar lingkaran itu, Ia jujur, tajam, tegas dengan sikap yang diambil, bersahaja. ${ }^{3}$

Dimasa kecilnya M. Natsir banyak menghabiskan waktu di surau, mengaji dan bersenda gurau layaknya anak kecil lainnya. Namun, pendidikan di surau tidaklah cukup. Natsir kecil sangat ingin belajar di sekolah modern. Ia berkeinginan untuk masuk ke Sekolah Rendah Belanda Hollandsch Inlandische School (HIS) Padang. Keinginan tersebut tidak terlaksana karena ia anak pegawai rendahan. Akhirnya Ia masuk sekolah partikelir ${ }^{4}$ HIS Adabiah di Padang. Di sini M.Natsir dititipkan kepada Makcik Ibrahim, ${ }^{5}$ meski hanya lima bulan di sini, Natsir kecil banyak belajar tentang kesederhanaan hidup. ${ }^{6}$ Kemudian ia dipindahkan ke HIS di Solok, oleh ayahnya ia dititipkan ke Haji Musa, seorang saudagar kaya di daerah itu. Pagi sekolah di HIS, sore hari di Madrasah Diniyah, dan malam hari ia mengaji dan memperdalam Bahasa Arab. Di Solok inilah ia pertama kali belajar bahasa Arab dan mempelajari hukum fikih kepada tuanku Mudo Amin yang dilakukannya pada sore hari di Madrasah Diniyah dan mengaji Al-Qur'an pada malam harinya.

Mohammad Natsir mendapatkan beasiswa untuk meneruskan pendidikannya di Meer Uitgebreid Lager Onderwijs (MULO) lalu kemudian ia pun bergabung dengan perhimpunan-perhimpunan pemuda seperti Pandu Nationale Islamietische Pavinderij serta Jong Islamieten Bond. Sesudah lulus dari MULO, ia selanjutnya pindah ke Bandung untuk belajar di Algemeene Middelbare School (AMS) sampai tamat pada tahun 1930. Di tahun 1928 hingga 1932, ia kemudian menjadi ketua Jong Islamieten Bond (JIB) Bandung.

Ia juga jadi pengajar setelah menerima pelatihan sebagai guru selama dua tahun di perguruan tinggi. Ia yang sudah memperoleh pendidikan Islam di Sumatera Barat pada mulanya juga memperdalam pengetahuan agamanya di Bandung, termasuk juga dalam bidang tafsir Al-Qur'an, hukum Islam, serta dialektika. Kemudian di tahun 1932, Natsir berguru pada Ahmad Hassan, yang nantinya akan menjadi tokoh organisasi Islam "Persatuan Islam". Masuknya Natsir ke dalam Persis ini membuat dirinya jadi orang yang kritis. Natsir tidak suka orang yang taklid, yakni menerima ilmu agama tanpa menyelidiki keshahihan dan dasar hukumnya. Adapun perkenalan dengan filsafat menjadikan dirinya

\footnotetext{
${ }^{3}$ Tempo, Natsir Politik Santun Di Antara Dua Rezim Seri Buku Saku Tempo: Tokoh Islam Di Awal Kemerdekaan (Jakarta: Gramedia, 2017). h.2

${ }^{4}$ Dalam KBBI partikelir memiliki arti swasta atau bukan untuk umum; bukan kepunyaan pemerintah, https://kbbi.web.id/partikelir

${ }^{5}$ Makcik Ibrahim bukanlah orang punya, penghasilanya pas-pasan, untuk makan seharihari M.Natsir harus mengencangkan ikat pinggang.

${ }^{6}$ Hepi Andi Bastoni, M. Natsir Sang Maestro Da'wah (Jakarta: Mujtama Press, 2008). h.2

${ }^{7}$ Luth. h.7
} 
orang yang kritis tapi tetap berpegang pada Batasan-batasan yang diperbolehkan Al-Qur'an dan Sunnah. ${ }^{8}$

Di tahun 1957, Mohammad Natsir menerima Bintang Nichan Istikhar (Grand Gordon) dari Raja Tunisia, Lamine Bey atas jasanya menolong perjuangan kemerdekaan rakyat Afrika Utara. Penghargaan internasional yang lain yakni Jaaizatul Malik Faisal al-Alamiyah pada tahun 1980, serta penghargaan dari sebagian ulama serta pemikir populer seperti Syekh Abul Hasan Ali an-Nadwi serta Abul A'la Maududi.'

Pada tahun 1980, Natsir dianugerahi penghargaan Faisal Award dari Raja Fahd Arab Saudi lewat Yayasan Raja Faisal di Riyadh, Arab Saudi. Ia memperoleh gelar doktor kehormatan dalam bidang Politik Islam dari Kampus Islam Libanon pada tahun 1967. Pada tahun 1991, ia kemudian memperoleh dua gelar kehormatan, yakni dalam bidang sastra dari Universitas Kebangsaan Malaysia serta dalam bidang Pemikiran Islam dari Universitas Sains Malaysia.

Selain itu, ketokohan M.Natsir ini diakui dan dipilih sebagai 100 tokoh besar Muslim di seluruh dunia pada abad XX, di dalam sebuah buku bertajuk, "100 Great Muslim Leaders of The 20 Century" yang diterbitkan oleh Institute of Objective Studies, New Delhi, 2005, sebuah jaringan IIIT di India. M.Natsir dipilih sebagai 100 pemimpin muslim besar muslim pada abad ke-20 bersama King Abdul Aziz, King Faisal, Hasan Al-Banna dan jajaran pemimpin Negara lainya, tokoh-tokoh pejuang kemerdekaan, tokoh pemikir dan penulis maupun jarajaran para pendidik dunia. ${ }^{10}$ Mohammad Natsir wafat pada 6 Februari 1993 di Jakarta, serta dimakamkan satu hari kemudian.

\section{Manhaj dan Gerakan Da'wah M. Natsir}

Islam adalah agama risalah dan da'wah, yang isinya adalah berita gembira dan peringatan untuk mengembalikan manusia kepada fitrahnya. Demikian ungkapan M. Natsir dalam memulai penjelasannya tentang apa itu da'wah. ${ }^{11}$ Secara garis besar dapat disimpulkan konsep da'wah Natsir, sebagai berikut;

Pertama, makna da'wah menurut Natsir, bahwa da'wah adalah kewajiban yang harus dipikul oleh setiap individu muslim maupun muslimah, karena dakwah adalah amar ma'ruf nahi mungkar yang merupakan syarat mutlak bagi kesempurnaan dan keselamatan hidup masyarakat. Da'wah bukan pula monopoli golongan ulama atau cendikiawan muslim tapi setiap individu karena ia adalah

\footnotetext{
${ }^{8}$ Hendra Gunawan, M. Natsir Dan Darul Islam (Jakarta: Media Dakwah, 2000). h. 20

9 'Mohammad Natsir', Wikipedia, 2020

<ttps://id.wikipedia.org/wiki/Mohammad_Natsir>.

${ }^{10}$ Lukman Hakiem, 100 Tahun Mohammad Natsir Brdamai Dengan Sejarah (Jakarta: Penerbit Republika, 2008). h.379 dan 374

${ }^{11}$ M. Natsir, Fiqhud Da'wah (Jakarta: Dewan Da'wah Islamiyah Indonesia, 2017). h.1
} 
pembawaan fitrah manusia selaku makhluk sosial yang kemudian dikukuhkan oleh wahyu. ${ }^{12}$ Kedua, landasan da'wah, yang dalam pandangan Natsir da'wah harus bersumberkan pada wahyu, Al-Qur'an dan Sunnah Rasulullah shallahu alaihi wasallam. Ketiga, tujuan da'wah, setidaknya ada tiga point dalam tujuan da'wah menurut Natsir. Yaitu: Mengajak atau menjadikan manusia hidup berdasarkan syari'at, Mengajak manusia kembali kepada fungsi hidup sebagai hamba Allah di muka bumi dan mengajak manusia untuk kembali kepada tujuan hidupnya yang hakiki, yaitu menyembah hanya kepada Allah saja. Keempat, tugas da'wah, tugas risalah para rasul dan da'wah para da'i adalah mempertemukan fitarh manusia dan wahyu ilahi. Sehingga seorang da'i harus mempersiapkan mental, ilmu dan cara serta adab da'wahnya. Kelima, sasaran da'wah, M. Natsir dalam da'wahnya hampir mencakup semua aspek kehidupan. Baik hubungan manusia dengan Tuhan maupun hubungan manusia dengan sesamanya. Dalam kehidupan social da'wah Natsir mencakup politik, ekonomi, pendidikan, budaya, pemikiran dan Kristenisasi. ${ }^{13}$

Adapun gerakan atau perjuangan da'wah M. Natsir dapat ditelusuri sejak beliau masih duduk di bangku sekolah setingkat SMA yaitu di Algemeene Middelbare School (AMS) Bandung. Beliau aktif di organisasi pemuda Islam, organisasi da'wah dan aktif melakukan diskusi-diskusi keagamaan. Secara umum gerakan da'wah Natsir dapat disebutkan sebagai berikut:

\section{Da'wah Melalui Jalur Pendidikan}

Pada hakikatnya da'wah adalah kegiatan mendidik manusia agar mengalami perubahan ke arah yang lebih positif. Sehingga dapat disimpulkan bahwa seorang pendidik juga adalah seorang da'i, yang melaksanakan perintah Allah menegakkan al-amru bil ma'ruf wannabyu 'anil munkar. ${ }^{14}$ Adapun tujuan dan dasar pendidikan menurut Natsir adalah tauhid yang tersimpul dalam dua kalimat syahadat, yang menjadi pokok kemerdekaan dan kekuatan ruhani, serta dasar dari kemajuan dan kecerdasan manusia. Bahwa tujuan mendidik peserta didik adalah menjadikan mereka memenuhi syarat-syarat penghidupan manusia sebagaimana tersimpul dalam Firman Allah "Wabtagi fimāa ätäkallähud-däral-äkhirata wa là tansa nașibaka minad-dun-yā....". dan juga supaya peserta didik dapat memenuhi kewajibannya sebaga hamba, yaitu hanya beribada kepada Allah semata

\footnotetext{
${ }^{12}$ Natsir, Fiqhud Da'wah. h.121

13 Safiin Mansur, 'Gerakan Dakwah M. Natsir Lewat Dewan Dakwah Islamiyah Indonesia (DDII)', Jurnal Adrikra, $3.2 \quad$ (2012), 17-30 $<$ https://doi.org/10.1017/CBO9781107415324.004>. h.20-24

14 Ali Maulida, 'KOMPETENSI PENDIDIK DALAM PERSPEKTIF M. NATSIR (Studi Analitis Pemikiran Pendidikan M. Natsir Dalam "Fiqhud Dakwah")', Al-Fikri Jurnal Studi Dan Penelitian Pendidikan Islam, 1.2 (2018), 39-46 <http://jurnal.unissula.ac.id/index.php/fikri/article/view/3207>. h.40
} 
sebagaimana Firman Allah "Wa mā khalaqtul-jinna wal-insa illā liya'budụn". ${ }^{15}$ Atas keprihatinan Natsir terhadap dunia pendidikan saat itu, dimana sekolahsekolah Belanda tidak memberikan kesempatan kepada pelajar-pelajar Islam untuk belajar agama di sekolah. Maka beliau mendirikan sekolah "Pendidikan Islam" (Pendis) yang dikelolahnya sendiri selama 10 tahun, yaitu 1932-1942 M. ${ }^{16}$

\section{Da'wah Melalui Media Massa}

Aktivitas da'wah Natsir melalui tulisan dimulai sejak ia masih sebagai pelajar di AMS Bandung. Ketika Natsir duduk di kelas 5 AMS, ia sudah membuat tulisan yang menganalisis tentang "Pengaruh Penanaman Tebu dan Pabrik Gula bagi Rakyat di Pulau Jawa" analisis yang ditulis dalam bahasa Belanda tersebut dibacakan di depan kelas yang membuat guru dan teman-temannya terpaku. Adapun tulisan Natsir yang pertama di media massa adalah tanggapan beliau terhadap dua cerama pendeta Christoffel yang diterbitkan dalam Koran Algemeen Indisch Dagblad. Sebagai da'i, Natsir terpanggil untuk memberikan koreksi terhadap kedua cerama yang banyak menyerang Islam tersebut. Selanjutnya tulisan-tulisan Natsir banyak diterbitkan di majalah, antara lain Pembela Islam, An-Nur, Pedoman Islam dan Panji Islam. Sejak 1936 Natsir sudah sering berpolemik dengan Soekarno melalui tulisan yang diterbitkan oleh Panji Islam secara berseri. Tulisan-tulisan M. Natsir yang bertebaran diberbagai media massa antara tahun 1935-1941 kemudian kumpulkan dalam Capita Selecta 1, dan pada tahun 1957 kembali diterbitkan Capita Selecta 2 yang memuat kumpulan pidato, karangan lepas, khutbah dan wawancara pers Natsir antara 1950-1955. ${ }^{17}$ Da'wah Natsir melalui tulisan terus berlanjut ketika beliau memimpin Dewan Da'wah Islamiyah Indonesia 1967-1993, setidaknya ada lima pernerbitan da'wah, yaitu majalah "Serial Media Da'wah" sebagai media da'wah kepada kaum terpelajar, majalah "Suara Masjid" konsumsi masyarakat awam, "Serial Khutbah Jum'at" sebagai bahan khutbah, Majalah "Sahabat" untuk anak-anak dan "Buletin Da'wah". ${ }^{18}$

\section{Da'wah Melalui Jalur Politik dan Pemerintahan}

Kegiatan da'wah politik Natsir dimulai sejak beliau aktif di dalam organisasi-organisasi pemuda Islam di Bandung seperti Jong Islamiten Bond

\footnotetext{
15 Adian Husaini, Pemikiran \& Perjuangan M. Natsir \& Hamka Dalam Pendidikan, I (Jakarta: Gema Insani, 2020). h.13

16 Abdullah, Dakwah Kultural Dan Struktural Telaah Pemikiran Dan Perjuangan Dakwah Hamka Dan M. Natsir (Bandung: Citapustaka Media Perintis, 2012). h.141-142

${ }_{17}$ M. Dzulfikriddin, Mohammad Natsir Dalam Sejarah Politik Indonesia, Peran Dan Jasa Mohammad Natsir Dalam Dua Orde Indonesia (Bandung: Mizan, 2010). h.38

18 Moch. Lukman Fatahullah Rais, Mohammad Natsir Pemandu Ummat (Jakarta: Bulan Bintang, 1989). h.15
} 
(JIB), Organisasi Budi Utomo dan lain-lain. Adapun terjun langsug dalam politik praktis pada tahun 1930 sebagai anggota Partai Serikat Islam (PSI), kemudaian pada tahun 1938 bergabung dalam Partai Islam Indonesia (PII) dan menjadi ketua PII cabang Bandung. Pasca proklamasi kemerdekaan RI, Natsir menfokuskan perhatianya dalam politik sebagai anggota Komite Nasional Indonesia Pusat (KNIP), bahkan kemudian terpilih menjadi Badan Pekerja KNIP dan kemudian menjadi wakil ketua badan itu. ${ }^{19}$ Tentu saja dalam aktivitas politiknya, Natsir adalah seorang da'i yang politisi, sehingga semua kegiatan politik beliau senantiasa dibingkai dengan nilai-nilai Islam dan dilakukan dalam rangka da'wa Islam. Berikut beberapa da'wah politik Mohammad Natsir melalui lapangan Parlementer, lapangan pemerintahan dan lapangan pembinaan umat dalam basis "da'wah melalui jalur politik":

1. Mengupayakan dan memperjuangkan Islam sebagai dasar negara

2. Menerapkan politik yang berasaskan Islam, bagi Natsir, konstituante harus bebas dari tekanan-tekanan dan saling terbuka dalam menyampaikan gagasan

3. Berusaha agar segala urusan-urusan yang mengenai kepentingan kehidupan umat diputuskan dan diselesaikan dengan dasar musyawarah.

4. Menyusun tenaga umat yang tertib dengan membangunkan peri kehidupan lahir bathin, mendidik sifat, pengertian, watak, akhlaq, dan lain-lain.

5. Mengupayakan wajib belajar bagi seluruh warga negara, minimum mengikuti pendidikan sekolah dasar, adapun pendidikan di sekolahsekolah agama (madrasah dan pesantren), dianggap telah memenuhi kewajiban belajar.

6. Berdasarkan dasar negara "Ketuhanan Yang Maha Esa", Mengusulkan pendidikan Agama sebagai kurikulum wajib meskipun pada akhirnya ditentang oleh partai PKI dan PNI karena dianggap memaksakan agama kepada rakyat.

7. Menyatukan kembali Negara Kesatuan Republik Indonesia melalui Mosi Integral Natsir.

Adapun bentuk Integrasi Kepemimpinan Politik dan Da'wah Mohammad Natsir dalam Catatan Sejarah berbasis "Berpolitik melalui Jalur Da'wah" adalah menempatkan da'wah terhadap penguasa sebagai prioritas. Kepada penguasa, beliau selalu berda'wah dengan melakukan sosial support, sosial control, dan control social participant. Ke bawah beliau melakukan attarbiyah ash-shabihah.

${ }^{19}$ Dzulfikriddin. h. 25-27 
Karena itu, apapun yang terjadi dalam pemerintahan, beliau selalu mencermati. Yang baik beliau dukung, yang akan mengahancurkan umat, dikoreksi, dan diperbaiki dengan dialog. Sedangkan ke bawah, beliau mencerdaskan umat. Inilah yang menjadi perpaduan yang seimbang jalur da'wah Mohammad Natsir sebagai politisi Islam dan Da'i yang berpolitik, Mohammad Natsir selalu mencari jalan untuk memperjuangkan da'wah Islam di muka bumi. ${ }^{20}$

\section{Da'wah melalui Dewan Da'wah Islamiyah Indonesia}

Natsir menyadari kalau dirinya dan kawan-kawan tidak lagi diberi kesempatan oleh pemerintah Orde Baru untuk berda'wah melalui jalur politik praktis, maka beliau mengingatkan "Jangan terus bertopang dagu atau menggerutu dipinggir jalan. Tapi harus terjun ke dalam bidang nonpolitik, bidang pembinaan umat lahir dan batin". ${ }^{21}$ Maka pada tanggal 26 Februari 1967 di Masjid Al-Munawarah Dewan Da'wah Islamiyah Indonesia didirikan, dengan program utama kaderisasi dan pembekalan da'i, penelitian serta penerbitan sebagai bekal bagi para da'i. ${ }^{22}$ Dalam melahirkan kader da'i yang tangguh, maka Natsir mencanangkan tiga pilar pembangunan umat, yaitu: masjid, pesantren dan kampus. Melalui pesantren diharapkan lahir ulama yang intelektual, dari kampus lahir intelektual yang ulama dan masjid melahirkan jama'ah yang shalih dan muslih, jama'ah pendukung gerakan da'wah. ${ }^{23}$

\section{HASIL DAN DISKUSI}

\section{Toleransi Menurut M. Natsir}

Untuk melihat konsepsi Natsir tentang toleransi, dapat kita baca melalui tulisan maupun pidato-pidato beliau. Diantaranya adalah pidato bilaiu dihadapan 15.000 rakyat yang menghadiri rapat samudra di Tanjung Karan:

"Agama Islam memberantas intoleransi agama serta menegakekan kemerdekaan beragama dan meletakkan dasar-dasar bagi keragaman bidup antar agama. Kemerdekaan menganut agama adalah suatu nilai bidup, yang dipertabankan oleh tiap-tiap muslimin dan

20 Siti Nur Fadlilah, KEPEMIMPINAN POLITIK DAN DA'WAH MOHAMAD NATSIR (Analisis History Kepemimpinan Politik Dan Da'wah Mobammad Natsir Tabun 1949-19993), Tesis Pada Program Pasca Sarjana Magister Ilmu Dakwah Universitas Islam Asy-Syafi'iyah (Jakarta, 2019). h.125-130

21 Lukman Hakiem, Biografi Mohammad Natsir Kepribadian, Pemikiran Dan Perjuangan (Jakarta: Pustaka Al-Kautsar, 2019). h.518

22 Tiar Anwar Bachtiar, Setengah Abad Dewan Da'wah Berkiprah Mengokobkan NKRI (Jakarta: Dewan Da'wah Islamiyah Indonesia, 2017). h. 88 dan 105

${ }_{23}$ Ujang Habibi, 'Model Pendidikan Kader Da'i Mohammad Natsir', Jurnal Dakwah Risalab Merintis Da'wah Melanjutkan, $1.2 \quad$ (2018), 17-37 <http://jurnalstidnatsir.ac.id/index.php/dakwah/article/view/9>. h.25 
muslimat. Islam melindungi menyembah Tuhan menurut agama masing-masing, baik di Masjid maupun gereja". Demikian pidato M. Natsir. Beliau menambahkan "Kami umat Islam berseru kepada seluruh teman sebangsa yang beragama lain, babwa Negara ini adalah Negara kita bersama, yang kita tegakkan untuk kita besama, atas dasar toleransi dan tenggang rasa, bukan untuk golongan khusus. Kami berseru sebagaimana seruan Muhammad kepada sesama warga Negara yang berlainan agama, kami diperintabkan supaya menegakekan keadilan dan keragaman diantara saudara". ${ }^{24}$

Dari pidato Natsir ini, sangat jelas terlihat bagaimana pemahaman beliau tentang toleransi, yaitu tasamub dalam Islam. Bagi Natsir dasar toleransi adalah AlQur'an dan Sunnah Nabi Muhammad serta pengamalan para sahabat dalam melaksanakan ajaran Islam dalam peri kehidupan antar agama. Toleransi yang diajarkan Islam bukanlah suatu toleransi yang bersifat pasif tapi aktif. Ia aktif menghargai dan menghormati keyakinan orang lain. Aktif dan bersedia senantiasa mencari titik persamaan diantara bermacam-macam perbedaan.

Toleransi Islam adalah menegakkan argumentasi, hujjah yang kuat tentang kebenaran namun jika tetap ditolak, tidak dipaksakan, karena Islam memeliki tuntunan untuk mengatakan apa yang termaktub dalam surat al-Kafirun ayat 6:

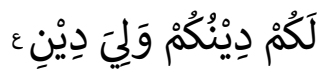

"Untukmu agamamu, dan untukkulah, agamaku."

Dan juga dalam surat al-Baqarah ayat 256:

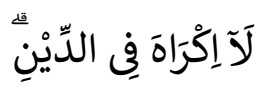

"Tidak ada paksaan untuk (memasuki) agama (Islam)..."

Jadi prinsip utama toleransi dalam Islam adalah tidak memaksakan agama, bukan menerima kebenaran agama lain. Ajaran toleransi Islam ini bukan hanya terdapat dalam teks, tetapi telah dibuktikan dengan penerapannya dalam kehidupan da'wah umat Islam. Pada awal Islam, suku-suku di Jazirah Arab masuk Islam secara sukarela, karena argumentasi, karena kagum pada pribadi Nabi SAW, karena konsep tauhid dalam Islam dan lain sebagainya. ${ }^{25}$ Konsep seperti ini pulalah yang coba dipraktekkan oleh M. Natsir dalam kegiatan da'wahnya di Indonesia.

Natsir mengingatkan bahwa toleransi antar umat beragama jangan diartikan "Yang penting rukun, jangan cekcok. Dan untuk itu mengalalah sedikit dalam persoalan agama". kebebasan beragama sebagaimana dijamin UUD 45, adalah

${ }^{24}$ M. Natsir, Capita Selecta 2 (Jakarta: Abadi, 2008). h.385

${ }^{25}$ Lukman, 'Memaknai Toleransi Dalam Menciptakan Kerukunan Antar Umat Beragama (Tela'ah Pemikiran Kerukunan Umat Beragama A. Mukti Ali)', Jurnal Dakwah Risalah Merintis Da'wah Melanjutkan, $3.1 \quad$ (2020) $\quad$ http://jurnalstidnatsir.ac.id/index.php/dakwah/article/view/61>. h.4 
kebebasan setiap pemeluk agama untuk dapat mengamalkan ajaran agamanya tanpa diganggu oleh usaha-usaha "kampanye" agama lain. ${ }^{26}$

\section{Penerapan Toleransi Natsir dalam Da'wah}

Pada sub pembahasan ini akan mencoba untuk mengelaborasi bagaimana pelaksanaan toleransi Natsir dalam kegiatan da'wahnya di berbagai bidang, khususnya da'wah beliau dalam dunia politik dan da'wah hubungan antar agama.

\section{Toleransi Da'wah Antar Agama Natsir}

Mohammad Natsir adalah tokoh Islam yang aktif menda'wahkan terwujudnya kehidupan antar umat beragama yang toleran di Indonesia. Hal ini terlihat dari usaha-usaha yang dilakukannya, baik ketika menjadi pejabat di pemerintahan, maupun ketika ia berada di luar pemerintahan sebagai orang biasa. Da'wah kerukunan antar umat beragama yang ditawarkan Natsir adalah da'wah yang penuh dengan nilai-nilai toleransi dan jauh dari da'wah yang menghujat, melecehkan dan merendahkan pemeluk agama lain. Setidaknya ada tiga langkah da'wah yang ditempuh Natsir terkait hubungan antar umat beragama di Indonesia:

Pertama, Aktif membangun dialog antar umat bergama, dalam berbagai forum Natsir sangat vocal menyuarakan terciptanya kerukunan antar umat beragama. ${ }^{27}$ Seperti dalam munyawarah antar umat beragama pada tanggal 30 November 1967, dalam forum ini Natsir menyerukan untuk hidup berdampingan dengan saling menghormati identitas agama masing-masing. Tidak menjadikan seseorang yang sudah memeluk suatu agama sebagai sasaran pemurtadan, karena hal seperti itulah yang menjadi akar masalah dari ketegangan antar beragama. Natsir menegaskan bahwa dalam Islam sendiri ada kode etik, seperti tidak boleh memaksakan agama kepada orang lain, bahwa Islam tidak menganggap umat Kristen sebagai orang-orang heiden atau animis yang belum beragama. Umat Kristen bagi Islam punya kedudukan sendiri yaitu sebagai Ahli Kitab. Natsir juga menyerukan agar sama-sama merawat keutuhan Negara Kesatuan Republik Indonesia sebaga Negara bersama, bukan Negara kelompok tertentu atau agama tertentu. $^{28}$

Kedua, Mengusulkan Modus Vivendi, sebagai salah satu bentuk toleransi da'wah Natsir dalam mewujudkan kerukunan antar agama adalah beliau mengusulkan adanya modus vivendi antar umat beragama di Indonesia. Modus

${ }^{26}$ M. Natsir, Percakapan Antar Generasi Pesan Perjuangan Seorang Bapak (Jakarta: Dewan Da’wah Islamiyah Indonesia, 2019). h.94

${ }^{27}$ Bachtiar. h.326

${ }^{28}$ M. Natsir, Islam Dan Kristen Di Indonesia (Bandung: Bulan Sabit, 1969). h.191 
vivendi adalah kesepakatan bersama antara pemeluk lain-lain agama untuk hidup berdampingan secara damai, yang menjamin keragaman hidup antar agama, dengan tidak mengkhianati keyakinan agama masing-masing. ${ }^{29}$ Isi dari modus vivendi ini adalah: a) Hidup berdampingan dengan baik, saling menghargai dan menjunjung toleransi antar agama, b) Semua agama di Indonesia merasakan hidup, c) Terwujudnya perdamaian antara masyarakat yang memiliki perbedaan agama di Indonesia dengan kepentingan pembangunan nasional. ${ }^{30}$ Natsir berkeyakinan kalau modus vivendi ini berlaku maka banyak hal bisa dilakukan bersama oleh Umat Kristen dan Umat Islam dalam menghadapi atheism dan mencegah kerusakan moral yang telah melanda masyarakat dewasa ini, bersamasama memulihakn kesusilaan dan budi pekerti yang sesui watak masyarakat Indonesia yang beragama. ${ }^{31}$ Natsir sebagai seorang muslim sangat optimis dapat memenuhi modus vivendi ini, karena dalam menjalankan kewajiban da'wah, Islam memiliki kode etik seperti tidak boleh memaksakan keyakinan agama pada orang lain, dan juga Umat Kristen dalam pandangan Islam adalah Ahli Kitab bukan masyarakat heiden atau animisme.

Ketiga, Gigih dalam mensosialisasikan konsep Islam tentang hubungan antar agama. Inilah toleransi da'wah Natsir yang sangat tinggi berkaitan dengan hubungan antar agama di Indonesia, beliau senantiasa menghindari kekerasan dan penghasutan umat dalam merespon agama lain yang berusaha menyerang Islam. Bagi Natsir umat lain-lain agama itu, belum bisa hidup berdampingan dengan Islam karena mereka belum megetahui konsep-konsep Islam dalam berinteraksi dengan umat lain. Umat lain tersebut belum mengetahui betapa Islam sangat memuliakan dan menghargai keyakinan agama lain. Dalam suatu kesempatan Natsir mengatakan bahwa "Ada semacam ketakutan non Muslim terhadap Islam terkait kebebasan beragama, meski itu sudah dijamin oleh undang-undang, dikalangan anggota parlemen ketakutan ini sudah hilang setelah ketua fraksi Masyumi membentangkan pendirian Islam tentang kebebasan beragama, namun kekhawatiran di dalam masyarakat tentang sikap umat Islam terhadap kemerdekaan beragama ini masih ada, maka kewajiban bagi kita berusaha dengan giat untuk menghilangkan ketakutan-ketakutan tersebut". ${ }^{32}$ Oleh karena itu dalam berbagai kesempatan dan momen Natsir selalu menyampaikan tentang posisi Islam terhadap pemeluk agama lain yang sangat toleran. Maka kita jumpai

${ }^{29}$ M. Natsir, Mencari Modus Vivendi Antar Ummat Beragama Di Indonesia (Jakarta: Dewan Da'wah Islamiyah Indonesia, 2005). h.13

${ }^{30}$ Indria Jami'atul Rohmah, M. NATSIR D AN KRISTENIS ASI DI INDONESLA (Studi Tindakan M.Natsir Terbadap Gerakan Kristenisasi Di Indonesia Tahun 1965-1979), Skripsi Pada Fakultas Adab Dan Humaniora UIN Sunan Ampel (Surabaya, 2013) < http://digilib.uinsby.ac.id/33333/>. h.61

31 Syafi'in Mansur, 'PANDANGAN M. NATSIR TENTANG MISSI KRISTEN DI INDONESIA', Aqlania Jurnal Filsafat Dan Teologi Islam, 2.2 (2011), 137-52 <http://repository.uinbanten.ac.id/id/eprint/3328>. h.146

32 Natsir, Capita Selecta 2. h. 313 
berbagai tulisan Natsir tentang konsep Islam dalam berinteraksi dengan non Muslim, antara lain buku berjudul Mencari Modus Vivendi Antar Umat Beragama di Indonesia, di dalamnya Natsir menjelaskan proposal aturan hidup berdampingan secara damai dan juga jaminan Islam tentang toleransi, menghormati dan menghargai umat agama lain. ${ }^{33}$ Buku lainnya adalah Hubungan Islam dan Kristen di Indonesia, berisi kumpulan tulisan Natsir tentang hubungan Islam dan Kristen seperti: "Islam memberantas Intoleransi Agama dan Tegakkan Beragama", "Keragaman hidup Antar Agama", Kode Toleransi Beragama dan lain-lain. ${ }^{34}$ Bahkan dalam usahanya mewujudkan kerukunan umat beragama bersama tokohtokoh lainnya Natsir berkirim surat kepada Paus Yohanes Paulus II yang menyerukan agar Paus Yohanes sebagai pimpinan tertinggi agama Kristen mengingatkan misionaris-misionaris di Indonesia untuk tidak menyalah gunakan kegiatan diakonia (pelayanan masyarakat). Natsir juga menyerukan agar ada toleransi, saling menghormati dan menghargai..$^{35}$

\section{Toleransi Da'wah Politik Natsir}

Dalam sebuah wawancara yang dilakukan oleh wartawan Tempo, Agus Basri pada tahun 1989, ketika ditanya apa yang belum tercapai dalam hidupnya, Mohammad Natsir menjawab "Yang belum tercapai sama seperti keinginan saya waktu jadi Perdana Mentri: orang-orang yang rukun, beragama, ada tasamuh, toleransi antar umat beragama yang satu dengan umat yang lain." 36

Dari pernyataan Natsir ini sangat jelas tergambar bahwa kegiatan beliau baik dalam dunia politik maupun diluar politik adalah da'wah Ilallah. Dan da'wah yang beliau lakukan adalah da'wah yang penuh dengan nilai-nilai toleransi, berikut rangkuman toleransi da'wah Natsir dalam dunia politik:

\section{Pertama, Toleransi Natsir Tentang Pancasila.}

Sebagai pimpinan Partai Masyumi, dalam melaksanan proses pengambilan keputusan partai, M. Natsir tidak memaksakan pendapat pribadinya untuk dijadikan sebagai keputusan partai. Misalnya, tentang pandangan partai terhadap suatu tema tentang hubungan Islam dengan Pancasila telah menimbulkan perbedaan pandangan diantara tokoh-tokoh Masyumi sendiri. Penafsiran Dr. Hamka terhadap pancasila dari sudut keislaman, memperlihatkan gambaran seolah-olah perbedaan antara Pancasila dengan Islam sebenarnya tidak ada.

\footnotetext{
${ }^{33}$ Natsir, Mencari Modus Vivendi Antar Ummat Beragama Di Indonesia.

${ }^{34}$ Natsir, Islam Dan Kristen Di Indonesia.

${ }^{35}$ M. Natsir, Surat Kepada Paus Yohanes Paulus II (Jakarta: Dewan Da’wah Islamiyah Indonesia, 1989). h.9

36 Agus Basri, Mohammad Natsir, Politik Melalui Jalur Da'wah (Jakarta: Dewan Da'wah Islamiyah Indonesia, 2019). h.41
} 
Adapun menurut Isa Anshary telah menyerang Pancasila dengan kata-kata keras, beliau tidak melihat ada persesuaian apa pun antara Islam dan Pancasila, "seseorang yang sudah bejat imanya saja yang ingin mempertahankan Pancasila itu." 37

Berbeda dengan Hamka dan Isa Anshary, Mohmmad Natsir mengemukakan pandangan yang lebih toleran mengenai Pancasila. Beliau memberikan ceramah yang membahas hubungan antara pancasila dengan Islam, Mohammad Natsir yakin bahwa perumus Pancasila, yang mayoritasnya adalah Muslim, tidak akan merumuskan sesuatu yang bertentanagn secara asasi dengan Islam. Pancasila, kata Natsir "bukanlah sesuatu yang asing bagi Islam". ${ }^{38}$

Di tengah-tengah perbedaan pandangan mengenai pancasila ini, Mohammad Natsir selaku pimpinan partai bersidang untuk menetapkan sikap resmi mereka. Setelah mendengarkan berbagai pandangan, badan itu memutuskan menerima pandangan M.Natsir sebagai sikap resmi partai Masyumi. Walaupun hal ini tidak dapat dipisahkan dari hakikat Natsir sebagai Ketua Pimpinan Partai yang berpengaruh, para Pimpinan Partai yang lain juga melihatnya sebagai jalan tengah antara pandangan yang diwakili oleh Hamka dan Isa Anshary.

Namun Natsir mengingatkan juga bahwa betapapun terdapat kesesuaian antara pancasila dengan Islam, tidaklah berarti bahwa:

"Pancasila adalah Islam" atau "Islam adalah Pancasila". Keduanya tetap berbeda, Islam kata Natsir, lebih luas daripada daripada "lima sila" di dalam Pancasila itu, lima sila itu "hanyalah mengambarkan sebagian ajaran Islam". ${ }^{39}$ Dari keterangan di atas menunjukan bahwasanya betapapun Mohammad Natsir adalah seorang tokoh Islam toleran dan Moderat, yang dengan ijtihadnya 'menerima' Pancasila namun juga tetap kokoh berdiri pada prinsipnya tentang esensi daripada Islam yang tidak akan mampu diwakilkan dengan Pancasila. Bagi Natsir, Pancasila dapat dipakai sebagai ideologi negara selama penafsiranya sesuai dengan AlQur'an dan Sunnah. ${ }^{40}$

\section{Kedua, Toleransi Natsir Tentang Islam Sebagai Dasar Negara}

Meskipun Natsir mengatakan "Pancasila bukanlah barang asing bagi Islam, dan tidak berlawanan dengan Al-Qur'an." Namun dalam sidang-sidang konstituante tahun 1955, Natsir adalah orang paling gigih memperjuangkan Islam sebagai

\footnotetext{
${ }^{37}$ Yusril Ihza Mahendra, Modernisme Dan Fundamentalisme Dalam Politik Islam (Jakarta: Paramadina, 1999). h.136

${ }^{38}$ Natsir, Capita Selecta 2. h.203

${ }^{39}$ Mahendra. h.137

${ }^{40}$ Gunawan. h. 22
} 
Dasar Negara bukan pancasila. ${ }^{41}$ Lalu apakah Natsir tidak lagi toleran terhadap pancasila?, tentu saja tidak karena bagi Natsir Pancasila tidak sepatutnya dijadikan alat untuk menghalangi pihak-pihak lain -termasuk golongan Islam- untuk memperjuangkan Dasar Negara yang dianggapnya lebih baik, selama golongan itu memperjuangkannya dengan cara-cara yang sah dan demokratis.

Pancasila sebenarnya diambil dari beribu-ribu sila yang terdapat dalam Islam, sehingga kalau Negara Islam terbentuk, maka pancasila akan dapat dipelihara dan akan dapat dipupuk bersama sila-sila yang lain. ${ }^{42}$ Dengan demikian penerimaan Natsir terhadap pancasila pasca kemerdekaan hingga tahun 1955 adalah sebuah tahapan dalam memperjuangkan Negara Islam secara konstitusional, sepanjang inti dan hakekat dari semua sila yang terkandung di dalamnya dipenuhi secara memadai dan dilaksanakan secara tepat. ${ }^{43}$

Islam tidak bisa dipisahkan dari negara. Natsir menganggap bahwa urusan kenegaraan pada pokoknya merupakan bagian integral dari risalah Islam. Negara adalah media atau alat yang dijadikan untuk membuat aturan yang sesuai dengan perintah Allah. Maka melalui kekuasaan negara nilai-nilai keislaman dapat ditegakkan. Karena negara punya kewenangan membuat, menjalankan dan menegakan aturan. Natsir menegaskan bahwa pola negara Islam anti terhadap kesewenang-wenanggan atau rezim yang otoriter, dalam pemerintahan Islam mengdepankan azas permusyawaratan dalam kontek bagaimana mengktualisasikan nilai-nilai yang sudah diatur dalam Al- Quran dan Hadist. ${ }^{44}$

Betapa pun kerasnya Natsir dalam memperjuangkan Islam sebagai dasar Negara, ketika mengalami kegagalan, Natsir tidak memaksakan kehendaknya, bersama teman-temanya tetap menyatakan kesetiaannya pada negara Republik Indonesia. Artinya Natsir tidak mendukung didirikannya negara tandingan yang dilakukan Kartosuwiryo dan kawan-kawan. Termasuk juga upaya Daud Bereueh dan Abdul Qahhar untuk membantu Kartosuwiryo dengan mendirikan DI/TII Aceh dan DI/TII Sulawesi Selatan. Meskipun antara Masyumi dan DI/TII sama-sama ingin mendirikan negara Islam yang berbentuk Republik. ${ }^{45}$

Ketiga, Mosi Integral Sebagai Salah Satu Bukti Sikap Toleransi Natsir

\footnotetext{
${ }^{41}$ Mhd Alfahjri Sukri, 'Islam Dan Pancasila Dalam Pemikiran Mohammad Natsir', Alfuad: Jurnal Sosial Keagamaan, 3.1 (2019), 82-96 < https://doi.org/10.31958/jsk.v3i1.1490>. h.92

${ }_{42}$ Natsir, Capita Selecta 2. h.408

${ }^{43}$ Sukri. h. 90

${ }^{44}$ Bismar Arianto, 'Kiprah Natsir Dalam Memperjuangkan Negara Islam Indonesia', KEMUDI: Jurnal Ilmu Pemerintahan, 2.02 (2018), 104-26

<http://ojs.umrah.ac.id/index.php/kemudi/article/view/761>. h.110-111

${ }^{45}$ Gunawan. h.37
} 
Pasca Konferensi Meja Bundar (KMB) tahun 1949 yang menandai pengakuan kedaulatan Republik Indonesia oleh Belanda, tidak serta merta mengakhiri tragedi yang melanda rakyat Indonesi. Bentuk Negara RIS-federalistik sebagai buah dari KMB telah menimbulkan perpecahan dan pertikaian antar anak bangsa sendiri, konflik terjadi dimana-mana antara pendukung dan penentang federalis. Ditengah kekacauan bangsa itulah Natsir tampil menyelesaikan konflik tersebut dengan Mosi Integralnya. Sebuah masalah besar bangsa dapat diselesaikan dengan jalan demokratis. ${ }^{46}$ Konsep "tasamuh" atau toleransi dari Natsir adalah bahagian yang tak terpisahkan dari konsep integralnya. Walau Natsir dan kawan-kawan di Konstituante memperjuangkan ideologi kenegaraan yang berdasarkan Islam, yang dimaksudkan adalah Islam yang tasamuh dan toleran itu, sesuai dengan ajaran Islam itu sendiri. ${ }^{47}$

Namun dibalik kesuksesan Mosi Integral Natsir ada usaha-usaha yang tidak murah dan tidak setiap orang bisa melakukanya, dengan usahanya berdiplomasi dengan sikap toleransi yang tinggi usaha-usaha M. Natsir membuahkan hasil yang fantastis. Mohammad Roem mencatat betapa dalam ikhtiarnya melicinkan jalan bagi Mosi Integral Natsir, Natsir berbicara dengan pemimpin fraksi paling kiri, Ir. Sakirman dari PKI dan dengan pemimpin paling kanan, Sahetapy Engel dari BFO. Ketika menyampaikan usul Mosi Integral di Parlemen M. Natsir mencoba menahan diri untuk tidak berbicara tentang federalisme atau unitarisme, karena menurut M. Natsir persoalanya tidak disitu. ${ }^{48}$ Atas pencapain gemilang ini tokoh utama PNI yang kristen, Arnold Mononutu, memberikan apresiasi yang sangat tinggi kepada Natsir dengan mengatakan; "Tanpa Mohammad Natsir tidak ada Kesatuan Republik Indonesia ini."

Tentu pujian Arnold sangat berlebihan, karena bagi Natsir semua itu adalah karunia dari Allah, dan apa yang dilakukannya adalah manispetasi dari keyakinannya sebagai seorang muslim: "Dan kalau ada dua golongan dari mereka yang beriman itu berperang hendaklah kamu damaikan antara keduanya! Tapi kalau yang satu melanggar perjanjian terhadap yang lain, hendaklah yang melanggar perjanjian itu kamu perangi sampai surut kembali pada perintah Allah. Kalau dia telah surut, damaikanlah antara keduanya menurut keadilan, dan hendaklah kamu berlaku adil; sesunggubnya Allah mencintai orang-orang yang berlaku adil" (Al-Hujurot: 6)

Ayat ini menunjukan adanya kewajiban dalam agama Islam untuk mendamaikan sesama umat Islam yang berselisih. Dan tentunya dalam proses

\footnotetext{
${ }^{46}$ Lukman Hakiem, M. Natsir Di Panggung Sejarah Republik (Jakarta: Republika, 2008). h.103

47 Roni Tobroni, 'Komunikasi Politik Mohammad Natsir', Communicatus: Jurnal Ilmu Komunikasi, 1.1 (2017), 39-60 < https://doi.org/10.15575/cjik.v1i1.1208>. h.49

48 Anwar Harjono, M. Natsir Sumbangan Dan Pemikiranya Untuk Indonesia (Jakarta: Dewan Da'wah Islamiyah Indonesia, 1995). h. 20
} 
menyatukan umat diperlukan sikap-sikap tenang dan toleransi yang tinggi untuk dapat melobi para elit-elit pimpinan politik yang jelas bersebrangan satu sama lain.

\section{Kempat, Toleransi Natsir Terhadap Lawan Politik}

Dalam catatan sejarah tercatat dengan baik ada hal-hal yang mengesankan dari sikap toleransi dan hubungan baik M. Natsir terhadap lawan-lawan politiknya yang berbeda pandangan dan idiologi. Tercatat DN Aidit, tokoh partai Komunis Indonesia, adalah musuh idiologi Natsir. Aidit memperjuangkan tegakkan Komunis di Indonesia, sebaliknya Natsir menginginkan Negara berdasarkan Agama Islam. Menurut Yusril, Natsir sering tidak bisa mengendalikan emosi ketika berdebat dengan Aidit di parlemen, "Kata Pak Natsir, rasanya dia ingin menghajar kepala Aidit dengan kursi" tapi hingga selesai sidang tidak ada kursi yang melayang, malah ketika meninggalkan ruang sidang, Aidit sering membawakannya segelas kopi, lalu mereka mengobrol akrab tentang keluarga masing-masing. Tidak ada kata-kata kasar atau permusuhan meski mereka debat hebat sebelumnya, bahkan tingkah lakunya seakan tidak terjadi apa-apa. Karena bagi Natsir "berdebat boleh keras, tapi tak boleh kasar". ${ }^{49}$

Selain bertentangan dengan Aidit, dalam parlemen Natsir juga berhadapan dengan tokoh-tokoh Parati Katolik dan Partai Kristen Indonesia, seperti I.J Kasimo dan A.M Tambunan. Kasimo dan teman-temannya bersikeras mempertahankan pancasila, sedangkan Natsir memperjuangkan idiologi Islam. Toh, sama dengan Aidit, Natsir juga berteman akrab dengan mereka. Bahkan ketika Natsir mengajukan Mosi Integralnya, mereka inilah yang berdiri tegak mendukungnya. Selain itu juga, saat Natsir menjabat Perdana Mentri, Natsir merangkul tokoh-tokoh Kristen duduk dalam kabinetnya. ${ }^{50}$

Keteladanan dalam berpolitik seperti inilah yang seharusnya menjadi warisan sikap politik berdemokrasi saat ini. Perbedaan pandangan politik dan agama tidak menganggu persahabatan dan persaudaraan sebangsa. Kesantunan dan pertemanan akrab pun tidak menghalangi untuk berdebat keras mempertahankan prinsip dan idiologi masing-masing.

\section{KESIMPULAN}

Uraian tentang nilai-nilai toleransi da'wah M. Natsir diberbagai bidang, menunjukkan ketulusan dan keikhlasan beliau dalam berjuang. Dari penelitian di atas, dapat ditarik kesimpulan tentang nilai-nilai toleransi da'wah M. Natsir sebagai berikut:

\footnotetext{
${ }^{49}$ Tempo. h.95-96

50 Tempo. h.98
} 
Pertama, toleransi Natsir adalah toleransi Islam yaitu tasamuh. Ini menjadikan konsep bertoleransi Natsir dalam menjalankan da'wahnya sangat jelas, karena didasarkan pada Al-Qur'an dan As-Sunnah serta pengamalan para Sahabat terhadap ajaran Islam.

Kedua, Islam adalah way of life, pakaian hidup seorang Muslim, sedangkan Negara adalah alat untuk menajalankan agama secara sempurna.

Ketiga, nilai-nilai toleransi da'wah Natsir dalam bidang politik adalah penerimaan terhadap pancasila dengan syarat diisi dengan hal-hal yang tidak bertentangan dengan Islam, memperjuangkan Islam sebagai dasar bernegara secara konstitusional dan menjaga keutuhan dan kesatuan berbangsa.

Keempat, nilai-nilai toleransi da'wah Natsir terkait hubungan antar umat beragama adalah beliau aktif dalam membangun dan ikut serata dalam dialogdialog antar agama, memberikan usulan-usulan sebagai kesepakatan hidup berdampingan antar agama, dan senantiasa menghilangkan kesalahpahaman yang terjadi antar pemeluk agama.

Kelima, Natsir senantiasa mendahulukan kepentingan umat dan kepentingan bersama sebagai bangsa daripada kepentingan pribadi atau partainya, Serta tidak menonjolkan perbedaan tapi selalu mencari titik persamaan.

\section{DAFTAR PUSTAKA}

Abdullah, Dakwah Kultural Dan Struktural Telaah Pemikiran Dan Perjuangan Dakwah Hamka Dan M. Natsir (Bandung: Citapustaka Media Perintis, 2012)

Arianto, Bismar, 'Kiprah Natsir Dalam Memperjuangkan Negara Islam Indonesia', KEMUDI: Jurnal Ilmu Pemerintahan, 2.02 (2018), 104-26 <http://ojs.umrah.ac.id/index.php/kemudi/article/view/761>

Bachtiar, Tiar Anwar, Setengah Abad Dewan Da'wah Berkiprah Mengokobkan NKRI (Jakarta: Dewan Da'wah Islamiyah Indonesia, 2017)

Basri, Agus, Mohammad Natsir, Politik Melalui Jalur Da'wah (Jakarta: Dewan Da'wah Islamiyah Indonesia, 2019)

Bastoni, Hepi Andi, M. Natsir Sang Maestro Da'wah (Jakarta: Mujtama Press, 2008)

Dzulfikriddin, M., Mohammad Natsir Dalam Sejarah Politik Indonesia, Peran Dan Jasa Mohammad Natsir Dalam Dua Orde Indonesia (Bandung: Mizan, 2010)

Fadlilah, Siti Nur, KEPEMIMPIN AN POLITIK DAN DA'WAH MOHAMAD NATSIR (Analisis History Kepemimpinan Politik Dan Da'wah Mohammad Natsir Tahun 1949-19993), Tesis Pada Program Pasca Sarjana Magister Ilmu Dakwah Universitas Islam Asy-Syafi'iyah (Jakarta, 2019)

Gunawan, Hendra, M. Natsir Dan Darul Islam (Jakarta: Media Dakwah, 2000) 
Habibi, Ujang, 'Model Pendidikan Kader Da'i Mohammad Natsir', Jurnal Dakwah Risalah Merintis Da'wah Melanjutkan, 1.2 (2018), 17-37 <http://jurnalstidnatsir.ac.id/index.php/dakwah/article/view/9>

Hakiem, Lukman, 100 Tabun Mohammad Natsir Brdamai Dengan Sejarah (Jakarta: Penerbit Republika, 2008)

- Biografi Mohammad Natsir Kepribadian, Pemikiran Dan Perjuangan (Jakarta: Pustaka Al-Kautsar, 2019)

—, M. Natsir Di Panggung Sejarah Republik (Jakarta: Republika, 2008)

Harjono, Anwar, M. Natsir Sumbangan Dan Pemikiranya Untuk Indonesia (Jakarta: Dewan Da'wah Islamiyah Indonesia, 1995)

Husaini, Adian, Pemikiran \& Perjuangan M. Natsir \& Hamka Dalam Pendidikan, I (Jakarta: Gema Insani, 2020)

Lukman, 'Memaknai Toleransi Dalam Menciptakan Kerukunan Antar Umat Beragama (Tela'ah Pemikiran Kerukunan Umat Beragama A. Mukti Ali)', Jumal Dakwah Risalah Merintis Da'wah Melanjutkan, 3.1 (2020) < http://jurnalstidnatsir.ac.id/index.php/dakwah/article/view/61>

Luth, Thohir, M. Natsir Da'wah Dan Pemikiranya (Jakarta: Gema Insani, 1999)

Mahendra, Yusril Ihza, Modernisme Dan Fundamentalisme Dalam Politik Islam (Jakarta: Paramadina, 1999)

Mansur, Safiin, 'Gerakan Dakwah M. Natsir Lewat Dewan Dakwah Islamiyah Indonesia (DDII)', Jumal Adrikra, 3.2 (2012), 17-30 $<$ https://doi.org/10.1017/CBO9781107415324.004>

Mansur, Syafi'in, 'PANDANGAN M. NATSIR TENTANG MISSI KRISTEN DI INDONESIA', Aqlania Jurnal Filsafat Dan Teologi Islam, 2.2 (2011), 137$52<$ http://repository.uinbanten.ac.id/id/eprint/3328>

Maulida, Ali, 'KOMPETENSI PENDIDIK DALAM PERSPEKTIF M. NATSIR (Studi Analitis Pemikiran Pendidikan M. Natsir Dalam "Fiqhud Dakwah")', Al-Fikri Jurnal Studi Dan Penelitian Pendidikan Islam, 1.2 (2018), 39-46 <http://jurnal.unissula.ac.id/index.php/fikri/article/view/3207>

'Mohammad

Natsir', Wikipedia, 2020 $<$ ttps://id.wikipedia.org/wiki/Mohammad_Natsir>

Natsir, M., Capita Selecta 2 (Jakarta: Abadi, 2008)

—. Fiqhud Da'wah (Jakarta: Dewan Da'wah Islamiyah Indonesia, 2017)

- Islam Dan Kristen Di Indonesia (Bandung: Bulan Sabit, 1969) -, Mencari Modus Vivendi Antar Ummat Beragama Di Indonesia (Jakarta: Dewan Da'wah Islamiyah Indonesia, 2005) 
- Percakapan Antar Generasi Pesan Perjuangan Seorang Bapak (Jakarta: Dewan Da'wah Islamiyah Indonesia, 2019)

- Surat Kepada Paus Yohanes Paulus II Jakarta: Dewan Da'wah Islamiyah Indonesia, 1989)

Rais, Moch. Lukman Fatahullah, Mohammad Natsir Pemandu Ummat (Jakarta: Bulan Bintang, 1989)

Rohmah, Indria Jami'atul, M. NATSIR D AN KRISTENIS ASI DI INDONESLA (Studi Tindakan M.Natsir Terbadap Gerakan Kristenisasi Di Indonesia Tabun 1965 1979), Skripsi Pada Fakultas Adab Dan Humaniora UIN Sunan Ampel (Surabaya, 2013) < http:// digilib.uinsby.ac.id/33333/>

Sukri, Mhd Alfahjri, 'Islam Dan Pancasila Dalam Pemikiran Mohammad Natsir', Alfuad: Jurnal Sosial Keagamaan, $3.1 \quad$ (2019), 82-96 <https://doi.org/10.31958/jsk.v3i1.1490>

Tempo, Natsir Politik Santun Di Antara Dua Rezim Seri Buku Saku Tempo: Tokoh Islam Di Awal Kemerdekaan (Jakarta: Gramedia, 2017)

Tobroni, Roni, 'Komunikasi Politik Mohammad Natsir', Communicatus: Jurnal Ilmu Komunikasi, 1.1 (2017), 39-60 < https://doi.org/10.15575/cjik.v1i1.1208> 